\title{
Enumeration of Microbes and Gas Production During Denitrification and Nitrogen Fixation Processes in Soil
}

\author{
Ghaly A.E. and K.N. MacDonald \\ Department of Process Engineering and Applied Science, Dalhousie University, Halifax, Canada \\ Email: Abdel.Ghaly@dal.ca
}

Received 2012-08-17, Revised 2012-09-11; Accepted 2012-09-11

\begin{abstract}
Dry plant material contains 2-4\% nitrogen, making it an essential nutrient for all plants. The nitrogen cycle regulates the pathways which transform nitrogen from a relatively inert dinitrogen gas to forms of organic nitrogen such as proteins and nucleic acids. Denitrification and nitrogen fixation are the two most important processes that remove and add nitrogen to the soil, respectively. The aim of the study was to gain information on the denitrification and nitrogen fixing activities in soil and sediment employing the acetylene technique and assuring the gas chromatography analysis by total plate count and most probably number. The results indicated that acetylene $(0.1 \mathrm{~atm})$ inhibited $\mathrm{N}_{2} \mathrm{O}$ reduction and caused stoichiometric accumulation of $\mathrm{N}_{2} \mathrm{O}$ during the conversion of $\mathrm{NO}_{3}{ }^{-}$to $\mathrm{N}_{2} \cdot \mathrm{N}_{2} \mathrm{O}$ was an obligatory intermediate in the sequence of steps between $\mathrm{N}_{2} \mathrm{O}^{-}$and $\mathrm{N}_{2}$. The appearance of $\mathrm{CO}_{2}$ and accumulation of $\mathrm{N}_{2} \mathrm{O}$ would be suitable criteria for the presence of denitrifiers in appropriately enriched media and the acetylene reduction test is a suitable assay for nitrogen fixing activity. There was an obligatory requirement for organic carbon as a carbon and energy source for denitrification and nitrogen fixation to take place. The results showed that acetylglucosamine can be used as a carbon and energy source for denitrification but not as a nitrogen source (C:N ratio of 5:1). $\mathrm{NH}_{4}{ }^{+}$has no effect on denitrification activity but it inhibited the nitrogenase activity. The presence of air in the gas phase affects both the denitrification and nitrogen fixing activity while adding $\mathrm{H}_{2} \mathrm{O}$ encouraged anaerobic conditions.
\end{abstract}

Keywords: Denitrification, Nitrogen fixation, Soil, Bacteria, Enumeration, $\mathrm{NO}_{3}^{-}, \mathrm{NO}_{2}^{-}, \mathrm{N}_{2} \mathrm{O}, \mathrm{N}_{2}, \mathrm{C}_{2} \mathrm{H}_{2}, \mathrm{C}_{2} \mathrm{H}_{4}$; $\mathrm{CO}_{2}$, Acetylglucosamine, Carbon, Energy

\section{INTRODUCTION}

Generally, natural agricultural soils are made of five major components as shown in Fig. 1: (a) organic matter (3-6\%), which is made of the remains of plants and animals and the products of their decomposition, (b) minerals (over 50\%), which are the products of rock breakage by physical and chemical processes, (c) air and water, which take up to $25-30 \%$ of the total volume of the soil depending on the soil type and moisture content and (d) the living organism (less than 1\%) which are the primary decomposers of dead organic matter and are responsible for the cycles of elements such as nitrogen, carbon, sulfur and phosphorus (Ghaly et al., 1999). A gram of soil may contain up to $10^{12}$ bacteria, $10^{6}$ algae, $10^{8}$ protozoa and $10 \mathrm{~km}$ of fungal hyphae (Trevors, 2010).
Fig. 1. Soil aggregates in the root zone

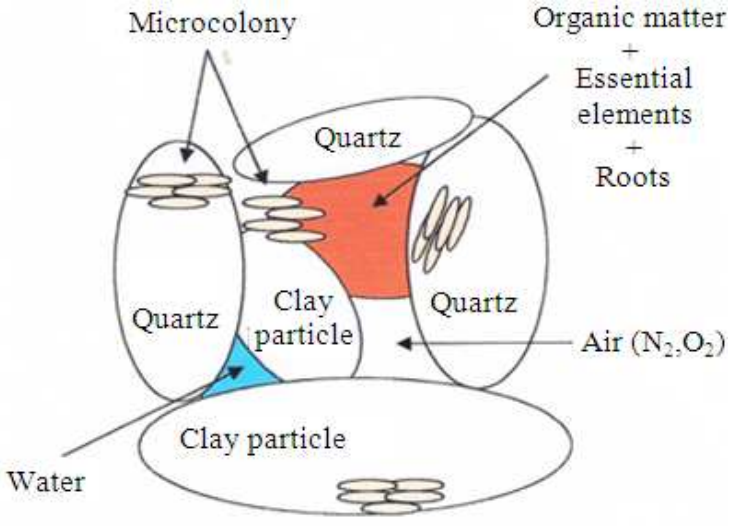




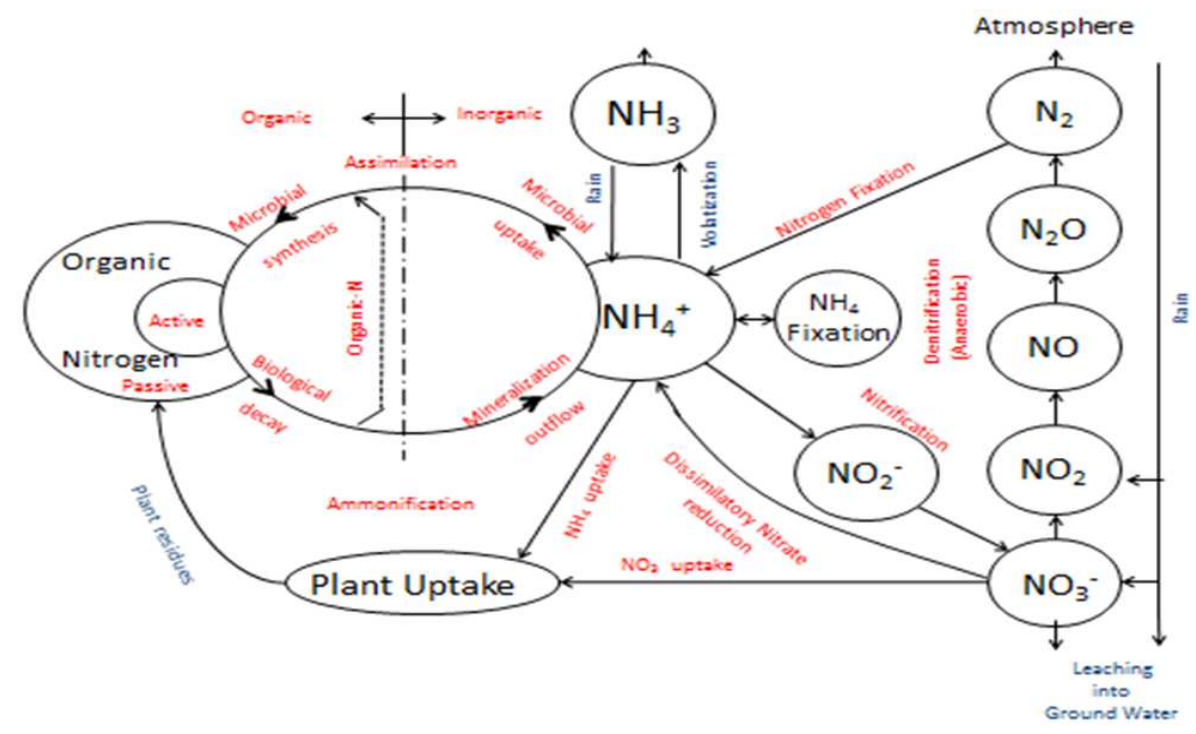

Fig. 2. The nitrogen cycle

Because of its very conspicuous importance to crop nutrition, the nitrogen cycle (Fig. 2) has attracted considerable attention from soil microbiologists, plant nutritionists and soil fertility specialists. Dry plant material contains $2-4 \%$ nitrogen. Nitrogen is a constituent of many organic compounds including amino acids, proteins, nucleic acids and enzymes. Through a sequence of microbial reactions, organic nitrogen is transformed into ammonium and then to nitrate (Cranfield et al., 2010). The plants absorb nitrogen from soil in the form of $\mathrm{NO}_{3}{ }^{-}$or $\mathrm{NH}_{4}{ }^{+}$. The uptake of $\mathrm{NH}_{4}{ }^{+}$is depressed under acidic conditions while the uptake of

$\mathrm{NO}_{3}{ }^{-}$is depressed under alkaline conditions. High concentrations of nitrogen can result in toxicity to plants as they become dark green in color with abundant foliage but with restricted root growth. Nitrogen deficiency also results in restricted growth and the plants will turn yellow from lack of chlorophyll especially in older leaves (Ross et al., 2011; Tremblay et al., 2012).

The overall transformations in which microorganisms are involved in the nitrogen cycle range from nitrogen gas to protein and other complex organic nitrogenous compounds with a tremendously large array of substrates between these extremes. A great many intricate enzymatic reactions are involved in bringing about these changes (Cranfield et al., 2010; Robertson and Kuenen, 1990). However, the two processes that remove and add nitrogen from the soil are denitrification and nitrogen fixation, respectively. The aim of this study was to examine soil and sediment for both denitrification and nitrogen fixation bacteria using gas chromatography and acetylene reduction techniques. The Most Probable Number (MPN) and Total Plate Count (TPC) were employed to assure the results of gas chromatography and $\mathrm{C}_{2} \mathrm{H}_{2}$ tests.

\section{DENITRIFICATION}

Certain microorganisms are capable of transforming nitrate and nitrite to nitrogen oxides and nitrogen gas by a process called denitrification, or dissimilatory nitrate reduction, which leads to a net loss of nitrogen from the soil. Denitrification is herein defined as the biochemical reduction of $\mathrm{NO}_{3}-\mathrm{N}$ and $\mathrm{NO}_{2}-\mathrm{N}$ to gaseous nitrogen in the form of Nitric Oxide (NO) and Nitrous Oxide $\left(\mathrm{N}_{2} \mathrm{O}\right)$ and molecular Nitrogen $\left(\mathrm{N}_{2}\right)$ Eq. 1 (Cranfield et al., 2010; Torrento et al., 2010):

$\mathrm{NO}_{3}^{-} \rightarrow \mathrm{NO}_{2}^{-} \rightarrow \mathrm{NO} \rightarrow \mathrm{N}_{2} \mathrm{O} \rightarrow \mathrm{N}_{2}$

Denitrification takes place in anoxic soils where the $\mathrm{O}_{2}$ is absent or the diffusion of $\mathrm{O}_{2}$ to the center of soil aggregate is slow allowing for anoxic micro sites (Burgin et al., 2010). Denitrification is a major process in the nitrogen cycle that returns $\mathrm{N}$ to the atmosphere thereby completing the biogeochemical cycle. Loss of nitrogen via denitrification is typically $2 \mathrm{~kg} / \mathrm{ha} / \mathrm{yr}$ for unfertilized soil (Hofstra and Bouwman, 2005).

In denitrification, nitrate serves as terminal electron acceptor for the oxidation of substrate. Many facultative anaerobic bacteria, predominantly of the genera Pseudomonas, Achromobacter, Alkaligenes and Paracoccus (Table 1) are capable of this reaction (Kim et al., 2008; Torrento et al., 2010). The reaction appears 
to be coupled with specific enzymes and cofactors. The electron transport system is identical under aerobic and anaerobic conditions (Lin et al., 2009). The aerobic and anaerobic systems for the oxidation of glucose by these facultative bacteria are as follows Eq. 2 and 3:

Aerobic system:

$$
\begin{aligned}
& \text { Facultative bacteria } \\
& \mathrm{C}_{6} \mathrm{H}_{12} \mathrm{O}_{6}+\mathrm{O}_{2} \longrightarrow 6 \mathrm{CO}_{2}+6 \mathrm{H}_{2} \mathrm{O}
\end{aligned}
$$

Anaerobic system:

$$
\begin{gathered}
\text { Facultative bacteria } \\
5 \mathrm{C}_{6} \mathrm{H}_{12} \mathrm{O}_{6}+\mathrm{HNO}_{3} \longrightarrow 30 \mathrm{CO}_{2}+4 \mathrm{HNO}_{3}+12 \mathrm{~N}_{2}
\end{gathered}
$$

Assuming availability of substrate $\left(\mathrm{NO}_{3}{ }^{-}\right.$or $\left.\mathrm{NO}_{2}{ }^{-}\right)$and reasonable conditions of temperature $\left(10-30^{\circ} \mathrm{C}\right)$ and $\mathrm{pH}(7.0-8.5)$, the denitrification reaction is strongly influenced by the partial pressure of $\mathrm{O}_{2}$ as well as the availability of an energy source (Calderer et al., 2010). Factors that indirectly affect $\mathrm{O}_{2}$ availability such as water logging have a significant effect on the denitrification process (Burgin et al., 2010).

It is generally assumed that during denitrification, bacteria oxidize organic substances completely to carbon dioxide concomitant with the reduction of nitrate or nitrite to nitric oxide, nitrous oxide and nitrogen. The ratio of carbon dioxide to nitrogen in denitrifying cultures corresponds to the theoretical ratio to be expected for complete oxidation of the organic substrate (Bothe et al., 2007; Warneke et al., 2011). In their carbon nitrogen balance experiments, Calderer et al. (2010) and Senbayram et al. (2012) clearly established that the organic substrate (carbon and energy source) is completely oxidized to carbon dioxide during denitrification, except for a small part that is converted to bacterial cells. Their results also indicated that the quantity of substrate assimilated to bacterial cells under anaerobic conditions was close to that observed under aerobic conditions.

Patriquin and Knowles (1974) suggested that disappearance of accumulated nitrite and presence of $\mathrm{N}_{2} \mathrm{O}$ in nitrite containing systems were reliable criteria for the presence of denitrifiers. Other researchers used gas chromatography to identify and quantitate gasses arising from denitrification including nitric oxide, nitrous oxide and molecular dinitrogen (Yoshinari and Knowles, 1976; Hara et al., 2009; Jia and Conrad, 2009; Warneke et al., 2011; Senbayram et al., 2012). However, Warneke et al. (2011) reported that certain denitrifying bacteria (including Agrobacterium tumerfaciens) lack nitrous oxide reductase and cannot complete the denitrification process to produce $\mathrm{N}_{2}$, generating $\mathrm{NO}$ as the end product of denitrification.
Table 1. Denitrifying bacteria of the genus Pseudomonias, Paracoccus, Alcaligenes and Achromobacter

\begin{tabular}{lll}
\hline Genus & Species & Reference \\
\hline Pseudomonias & putida & Dandie et al. (2007) \\
& stutzeri & Ward (1995) \\
& aureofaciens & Ward (1995) \\
& denitrificans & Ward (1995) \\
& atlantica & Ward (1995) \\
& fluorescens & Ward (1995) \\
& aeruginosa & Ward (1995) \\
& savastanoi & Dandie et al. (2007) \\
& brassicacearum & Dandie et al. (2007) \\
& chlororaphis & Dandie et al. (2007) \\
& frederiksbergensis & Dandie et al. (2007) \\
& grimontii & Dandie et al. (2007) \\
& kilonesis & Dandie et al. (2007) \\
& lini & Dandie et al. (2007) \\
& mandelii & Dandie et al. (2007) \\
& migulae & Dandie et al. (2007) \\
\hline Paracoccus & denitrificans & Ward (1995) \\
& halodinitrificans & Ward (1995) \\
\hline Alcaligenes & faecalis & Ward (1995) \\
& eutrophus & Hallin and Lindgren (1999) \\
& denitrificans & Hallin and Lindgren (1999) \\
\hline Achromobacter & piechaudii & Dandie et al. (2007) \\
& cycloclastes & Hallin and Lindgren (1999) \\
\hline
\end{tabular}

Nakajima et al. (2005) reported that the lack of significant gas production in inverted vials in the presence of denitrifier might result from: (a) toxicity or accumulated nitrite (b) inappropriate organic matternitrate ratio in the medium (c) formation of $\mathrm{N}_{2} \mathrm{O}$, which is highly soluble, but not $\mathrm{N}_{2}$ and (d) nitrate-nitrite suppression of gas formation by denitrifiers, with concomitant use of energy substrates by competing organisms in the mixed culture systems.

Studies on inhibition of Nitrous Oxide $\left(\mathrm{N}_{2} \mathrm{O}\right)$ reductase by azide $\left(\mathrm{N}_{3}{ }^{-}\right)$, Cyanide $\left(\mathrm{CN}^{-}\right)$and Dinitrophnol (DNP) in Pseudomonas denitrificans showed that $\mathrm{N}_{2} \mathrm{O}$ was an obligatory intermediate in the reduction of $\mathrm{NO}_{2}^{-}$to $\mathrm{N}_{2}$ (Warneke et al., 2011). Yoshinari and Knowles (1976) reported that $\mathrm{C}_{2} \mathrm{H}_{2}$ inhibited reduction of $\mathrm{N}_{2} \mathrm{O}$ by three denitrifying bacteria, Pseudomonas perfectomarinus, Pseudomonas aeruginosa and Micrococcus denitrificans. They also reported that during reduction of $\mathrm{NO}_{3}^{-}$or $\mathrm{NO}_{2}^{-}, \mathrm{C}_{2} \mathrm{H}_{4}$ caused accumulation of $\mathrm{N}_{2} \mathrm{O}$ with a stoichiometry which suggested that $\mathrm{N}_{2} \mathrm{O}$ is an obligatory intermediate in the reduction of $\mathrm{NO}_{2}^{-}$to $\mathrm{N}_{2}$ with all three species of denitrifiers.

Senbayram et al. (2012) reported that the ratio of $\mathrm{N}_{2} \mathrm{O}$ to $\mathrm{N}_{2}$ produced by a denitrifying soil is related to the initial $\mathrm{NO}_{3}^{-}$content available to the micro flora. High $\mathrm{NO}_{3}^{-}$ contents lead to greater $\mathrm{N}_{2} \mathrm{O}$ production which has a greater greenhouse effect and contributes to ozone depletion. 


\section{NITROGEN FIXATION}

If molecular nitrogen was completely inert biologically, the activities of the denitrifying bacteria would very rapidly deplete the biosphere of all nitrogen available for growth and life would cease on earth. Although atmospheric nitrogen is not a suitable nutrient for most organisms, it can be used by a few specialized types as a source of nitrogen for growth. It is these nitrogen fixing organisms that compensate for the losses of combined nitrogen due to denitrification and maintain a more or less constant amount of nitrogen in the biosphere through the process of nitrogen fixation (Cranfield et al., 2010; Jia and Conrad, 2009). Nitrogen fixation is herein defined as a biological process by which nitrogen gas $\left(\mathrm{N}_{2}\right)$ in the soil is converted into ammonium $\left(\mathrm{NH}_{4}\right)$ by either symbiotic or asymbiotic associations Eq. 4:

$$
\mathrm{N}_{2}+4 \mathrm{H}_{2} \mathrm{O} \stackrel{\text { Nitrogenase }}{\longrightarrow} 2 \mathrm{NH}_{4}+2 \mathrm{O}_{2}
$$

Nitrogen fixation is one of the most metabolically intensive processes regulated by the available cellular energy (Reed et al., 2011). In free nitrogen fixation energy needs must be met through either photosynthesis or the consumption of carbon based energy sources (organic matter). In the symbiotic association, the ectotrophic mycorrhizal fungi (which possess the enzyme nitrogenase) forms a sheath around the active fine roots of plants and provide them with $\mathrm{NH}_{4}$ while obtaining their carbohydrate (energy requirements) from the plant (Fig. 3). Because of the large surface area, fungi also obtain other soil minerals from the soil and transfer them to the plant roots. In the asymbiotic association, bacteria and blue green algae possess the enzyme nitrogenase and can fix $\mathrm{N}_{2}$ into $\mathrm{NH}_{4}$. However, this process takes place in soils that have high organic matter content which provide a ready source of energy to these microorganisms.

The nitrogen fixation process is controlled by $\mathrm{N}: \mathrm{P}$ ratio as phosphorus activates the gene required for the synthesis of the enzyme nitrogenase. Molybdenum (Mo) and iron $(\mathrm{Fe})$ are also required as they serve as structural compounds for nitrogenase. Investigations with cell-free preparation have implicated three similar two-component proteins (an $\mathrm{Fe}-\mathrm{Mo}$ protein, a $\mathrm{V}$-Fe protein and an $\mathrm{Fe}-\mathrm{Fe}$ protein), each of these protein pairs has been observed to produce an active $\mathrm{N}$ complex (enzyme nitrogenase) upon combination. Proteins from different genera appear to be very closely related, indicating broad generally applicable N fixation schemes (Jetten, 2008; Santos et al., 2012; Gaby and Buckley, 2011). Reed et al. (2011) indicated that organisms are not limited to expressing a single form of nitrogenase enzyme and may carry the genes necessary for encoding all three types. Nitrogenase is remarkably nonspecific, possessing the capability to reduce such compounds as nitrous oxide and acetylene (Keeney, 1973). The reduction of acetylene to ethylene has become the basis for a widely applied assay for nitrogen fixation Eq. 5 (Hara et al., 2009):

$$
\mathrm{C}_{2} \mathrm{H}_{2}+2 \mathrm{e}^{-}+2 \mathrm{H}^{+} \stackrel{\text { Nitrogenase }}{\longrightarrow} \mathrm{C}_{2} \mathrm{H}_{4}
$$

Bertics et al. (2010) stated that nitrogenase can reduce a number of substrates with a facility that is apparently dependent upon the number of electrons required for reduction. Acetylene $\left(\mathrm{C}_{2} \mathrm{H}_{2}\right)$ is an alternative substrate for nitrogenase and will compete effectively with $\mathrm{N}_{2}$ at the active site of the enzyme to be reduced to ethylene $\mathrm{C}_{2} \mathrm{H}_{4}$. The reduction of acetylene to ethylene requires two electrons whereas the reduction of $\mathrm{N}_{2}$ to $\mathrm{NH}_{3}$ requires six electrons so that nitrogenase activity as measured by acetylene reduction is theoretically three times as high as that rated for $\mathrm{N}_{2}$. Bertics et al. (2010) stated that in practice the equivalent ratio may be as high as 4 due to the inhibition of $\mathrm{H}_{2}$ production which normally occurs with the reduction of $\mathrm{N}_{2}$, thereby increasing the rate of reaction Eq. 6 :

$$
\mathrm{N}_{2}+6 \mathrm{H}^{+}+6 \mathrm{e}^{-} \stackrel{\text { Nitrogenase }}{\longrightarrow} 2 \mathrm{NH}_{3}
$$

Burns and Hardy (1975) reported that nitrous oxide and $\mathrm{C}_{2} \mathrm{H}_{2}$ are substrates for and competitive inhibitors of nitrogenase. Dalton and Whittenburry (1976) reported that the addition of $0.5 \mathrm{~mL}$ of acetylene immediately inhibited gas metabolism and growth of nitrogen fixing methanol oxidizing Methylococcus capsulatus. However oxygen concentration, $\mathrm{CO}_{2}$ production and growth were restored when methanol was added to the culture. When ethylene was added to a similar culture the rate of uptake and production of the other gases decreased to $45 \%$ of their normal values, indicating that metabolism was not completely halted.

Factors affecting nitrogen fixation include: (a) availability of energy source, (b) moisture content and (c) presence of $\mathrm{NO}_{3}$ and $\mathrm{NH}_{4}$ in soil. Vitousek and Hobbie (2000) reported that $65 \%$ of the variation in nitrogen fixation rates in tropical forest litters was accounted for in the variation in carbon availability. Accessible carbon substrate was observed as the most commonly limiting factor in litter decomposition. Low lignin litters (10-15\% lignin) fixed $0.9-1.3 \mathrm{mg}$ nitrogen $/ \mathrm{g}$ initial mass while high lignin litters $(25-30 \%$ lignin) fixed 0.03-0.06 $\mathrm{mg}$ nitrogen $/ \mathrm{g}$ initial mass. In a similarly designed experiment, Perez et al. (2010) found that the greatest factor affecting the rate of nitrogen fixation was the carbon to nitrogen ratio of the energy source provided. 


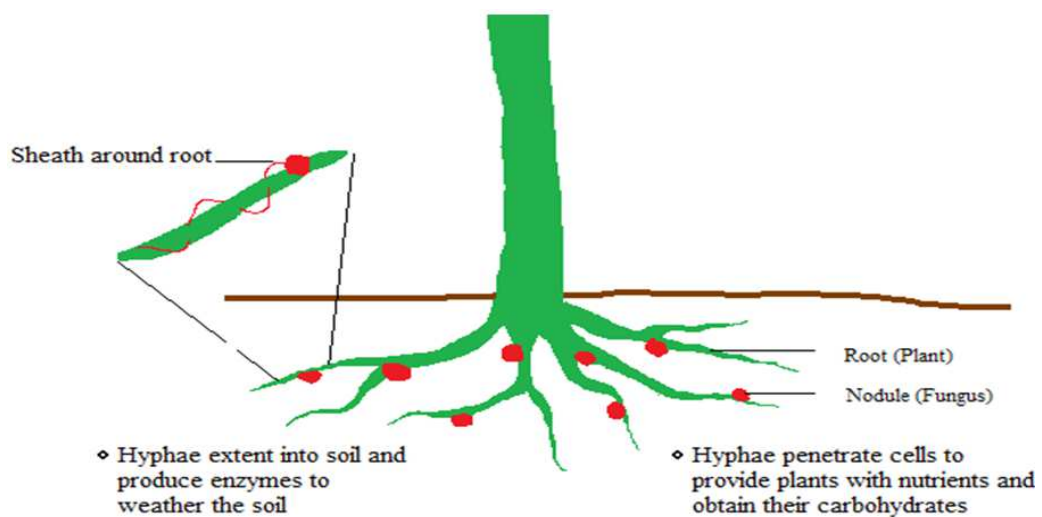

(a) Symbiotic association of mycorrhizal fungi and plant

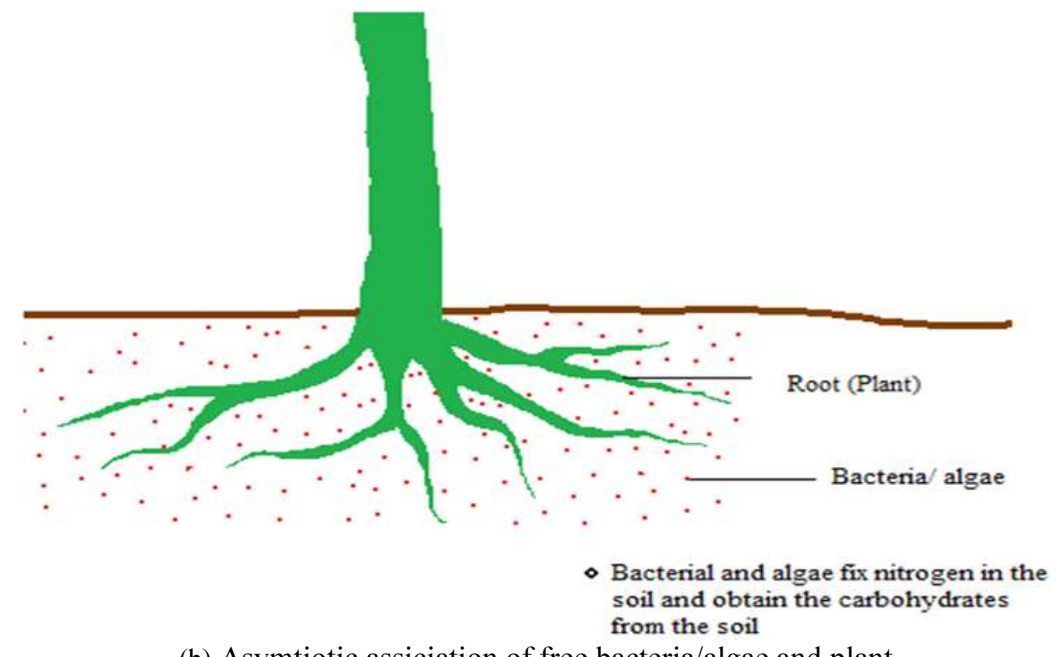

(b) Asymtiotic assiciation of free bacteria/algae and plant

Fig. 3. Symbiotic and asymbiotic nitrogen fixation.

They observed a 3.4 fold increase in nitrogen fixation when $\mathrm{C}: \mathrm{N}$ ratio of the litter used was changed from 50.6 to $78.9 \%$. It was hypothesised that the increased nitrogen fixation rates were due to an increased competitive advantage for nitrogen fixing bacteria in a low nitrogen environment.

Larrainzar et al. (2009) investigated the effect of mild drought conditions on the root nodule nitrogen fixation of the legume Medicago truncatula. Their results indicated that soil moisture was an important factor in the nitrogen fixation rate in soil. During drought conditions, decreases in nitrogen fixation occurred although increases were observed in soil carbon sources (including various sugars). Similarly, Zhao et al. (2010) reported a significant decrease in nitrogenase activity of biocrust when moisture content was reduced to below $20 \%$ field holding capacity. However, there was no significant variation in the nitrogenase activity reported when the moisture content varied from $40-100 \%$ field holding capacity.
Ohyama et al. (2008) reported the inhibition of root nodule growth within hours of the addition of nitrate or ammonia nitrogen. Changes in the level of nitrogen fixation were observed 24 hours after nitrate or ammonia addition. Salvagiotti et al. (2008) reviewed the literature on nitrogen fixation and found a negative exponential decay in the nitrogen fixation rate when the amount of nitrogen added as either ammonium or nitrate fertilizer increased.

\section{MATERIALS AND METHODS}

\subsection{Soil and Sediment Collection}

A Nova Scotia soil was obtained from a commercial farm in Turo Nova Scotia, $100 \mathrm{~km}$ from Halifax. The top vegetation/trash cover of the soil was scrapped away and the top $30 \mathrm{~cm}$ of the soil was removed with a shovel. The soil was placed in a heavy duty polyethylene bag and 
transported from the collection site to the Waste Management Laboratory, Dalhousie University, Halifax, Nova Scotia. The soil was washed with water 3 times to minimize the level of nutrients in it. The soil characteristics are presented in Table 2. The sediment was obtained from a natural wetland in the Waverly Game Sanctuary, approximately $25 \mathrm{~km}$ from Halifax, Nova Scotia. The sediment was collected in a plastic container and transported to the Waste Management Laboratory of Dalhousie University. The sediment characteristics are shown in Table 2.

\subsection{Experimental Design}

The denitrification and nitrogen fixation in soil and sediment were evaluated. The effects of gas phase composition (air or $\mathrm{N}_{2}$ ), addition of glucose ( 0 and $0.5 \%$ ), addition of $\mathrm{C}_{2} \mathrm{H}_{2}(0$ and $5 \mathrm{~mL})$, addition of water $(0,0.5,1.0,4.0$ and $4.5 \mathrm{~mL})$ and addition of a nitrogen source $\left(0, \quad \mathrm{NH}_{4}^{+}, \quad \mathrm{NH}_{4}+\mathrm{NO}_{3}, \quad\right.$ acetylglucosamine, acetylglucosamine $+\mathrm{NO}_{3}{ }^{-}$) were studied. The experiments were divided into seven groups with 4 flasks in each group (Table 3). Three replicated were carried out for each treatment. This resulted in 84 flasks.

\subsection{Experimental Procedure}

Ten grams of soil (or sediment) were placed into each of the $50 \mathrm{~mL}$ Erlenmeyer flasks. After closing with an appropriate size of serum stopper, some flasks were evacuated through a needle and back filled with $\mathrm{N}_{2}$ to one atmosphere. When required, $5.0 \mathrm{~mL}$ of gas phase was replaced with the same volume of acetylene $\left(\mathrm{C}_{2} \mathrm{H}_{2}\right)$ to give a final concentration of 0.1 atmospheres. Also, when desired $0.5 \mathrm{~mL}$ of glucose and/ or $0.5 \mathrm{NH}_{4}+, \mathrm{NO}_{3}{ }^{-}$and /or glucosamine was added to give a final concentration of $0.5 \% \mathrm{w} / \mathrm{w}$ glucose and $100 \mathrm{ppm} \mathrm{w} / \mathrm{w} / \mathrm{NO}_{3}^{-}-\mathrm{N}$. Water was added as desired. All flasks were incubated at room temperature for 7 days. Table 3 showed the treatment combinations and the analysis carried out on the samples.

\subsection{Gas Analyses}

The $\mathrm{CO}_{2}, \mathrm{~N}_{2} \mathrm{O}, \mathrm{C}_{2} \mathrm{H}_{2}$ and $\mathrm{C}_{2} \mathrm{H}_{4}$ measurements were carried out using a gas chromatograph (Hewlett Packard model HP 5980A, Palo Alto, California, U.S.A), with helium as a carrier gas (at a flow rate of $30 \mathrm{~mL} \mathrm{~min}^{-1}$ ) and a Poropak Q stainless steel column (152.4 x $3.2 \mathrm{~mm}$ O.D.). The column was set up in a bypass arrangement with a Molecular Sieve 5A 60/80 stainless steel column (152.4 x $3.2 \mathrm{~mm}$ O.D.). $1 \mathrm{~mL}$ of the gas samples was injected into the column and a switch valve was adjusted to store the nitrogen until the elution of the other compounds (carbon dioxide, nitrate, acetylene and ethylene). The injector and column temperatures were set to 150 and $45^{\circ} \mathrm{C}$, respectively. Detection was performed with a flame ionization detector as well as a thermal conductivity detector set to $250^{\circ} \mathrm{C}$.

\subsection{Bacterial Count Analysis}

Bacterial count of Azotobacter, Clostridium and qualitative enrichments of denitrifiers were performed. Plate counts were performed by creating tenfold dilutions of the soil in sterile water. To create the first dilution $\left(10^{-1}\right) 1 \mathrm{~g}$ of soil was added to a test tube with 9 $\mathrm{mL}$ of water and shaken to produce an even mixture. Further dilutions were prepared by pipetting $1 \mathrm{~mL}$ of the previous dilution into $9 \mathrm{~mL}$ of water until dilutions were made for $10^{-1}$ to $10^{-7}$. Agar plates of Azotobacter agar (manitol), clostridium agar and fluorescein denitrification agar were prepared for the bacteria counts by dissolving the ingredients listed in Table 4 in $1 \mathrm{~L}$ of distilled water and autoclaving. Spread plates were prepared by pipetting $0.1 \mathrm{~mL}$ of the respective dilution onto a labelled (specimen and dilution) agar plate and spreading with a sterile glass spreader. All samples were plated in triplicate. Agar plates were sealed, inverted and incubated for 48 hours at $30^{\circ} \mathrm{C}$. Plates that grew between 3 and 300 colonies were counted. The cell count was obtained by multiplying the plate count by the respective dilution, to obtain a value in cells/g soil.

\section{RESULTS}

Table 5 shows the data obtained from the gas chromatographic analysis and bacterial count from the experiments in which denitrification and nitrogen fixation were studied using the treatment combinations described in Table 3.

\subsection{Group 1 (Soil with $\mathbf{N}_{2}$ ).}

\subsubsection{Denitrification}

There was no $\mathrm{NO}_{3}^{-}$added to the soil samples. Therefore, the denitrification process did not proceed. The presence of $0.5 \mu$ moles of $\mathrm{N}_{2} \mathrm{O}$ in flask 4 may be from the initial gas phase or due to traces of $\mathrm{NO}_{3}{ }^{-}$or $\mathrm{NO}_{2}^{-}$in the soil sample which were converted to $\mathrm{N}_{2} \mathrm{O}$ and the later accumulated due to the inhibitory effect of $\mathrm{C}_{2} \mathrm{H}_{2}$ on the conversion of $\mathrm{N}_{2} \mathrm{O}$ to $\mathrm{N}_{2}$. The numbers of denitrifiers obtained by the most probably numbers (MPN) methods were smaller than that of other flasks (other groups where denitrification proceeded) which supported the results obtained by gas chromatography analysis.

\subsubsection{Nitrogen Fixation}

There was no nitrogen-fixing activity in flask 1 and 2 due to the lack of organic carbon which required as a carbon and energy source. The $1.4 \mathrm{n}$ moles $\mathrm{C}_{2} \mathrm{H}_{4}$ detected in flask 2 may be due to organic carbon traces in the soil sample. 
Table 2. Soil and sediment characteristics

\begin{tabular}{lll}
\hline Parameter & Soil & Sediment \\
\hline Soil type & Stewiack & Queen \\
Texture & Medium & Moderately fine \\
Drainage & Well to moderately drained & Moderately drained \\
Permeability & Slow $\left(0.36 \times 10^{-2}\right)$ & Slow $\left(25 \times 10^{-2}\right)$ \\
Field bulk density & $1.4 \mathrm{~kg} / \mathrm{m}^{3}$ & $1.3 \mathrm{~kg} / \mathrm{m}^{3}$ \\
pH & 6.5 & 5.9 \\
Particle size & 21 clay, 20 silt, 59 sand & 25 clay, 23 silt, 54 sand \\
Classification & Sandy loam & Sandy clay loam \\
\hline
\end{tabular}

Table 3. Experimental parameters

\begin{tabular}{|c|c|c|c|c|c|c|c|}
\hline Group & Sample & Flask & Gas Phase & $\begin{array}{l}0.5 \mathrm{ml} \text { Glucose } \\
(0.5 \% \mathrm{w} / \mathrm{w})\end{array}$ & $\begin{array}{l}0.5 \mathrm{ml} \mathrm{N} \\
(100 \mu \mathrm{g} / \mathrm{g})\end{array}$ & $\begin{array}{r}5 \mathrm{ml} \mathrm{C}_{2} \mathrm{H}_{2} \\
(0.1 \mathrm{~atm})\end{array}$ & $\mathrm{H}_{2} \mathrm{O}(\mathrm{ml})$ \\
\hline \multirow[t]{4}{*}{$\overline{1}$} & Soil & 1 & $\mathrm{~N}_{2}$ & - & - & - & 1.0 \\
\hline & & 2 & $\mathrm{~N}_{2}$ & - & - & + & 1.0 \\
\hline & & 3 & $\mathrm{~N}_{2}$ & + & - & - & 0.5 \\
\hline & & 4 & $\mathrm{~N}_{2}$ & + & - & + & 0.5 \\
\hline \multirow[t]{4}{*}{2} & Soil & 1 & $\mathrm{~N}_{2}$ & + & - & + & 0.5 \\
\hline & & 2 & $\mathrm{~N}_{2}$ & + & $\mathrm{NH}_{4}^{+}$ & + & - \\
\hline & & 3 & $\mathrm{~N}_{2}$ & + & $\mathrm{NO}_{3}^{-}$ & + & - \\
\hline & & 4 & $\mathrm{~N}_{2}$ & + & $\mathrm{NH}_{4}^{+} \mathrm{NO}_{3}^{-}$ & + & - \\
\hline \multirow[t]{4}{*}{3} & Soil & 1 & $\mathrm{~N}_{2}$ & - & $\mathrm{NO}_{3}^{-}$ & - & 0.5 \\
\hline & & 2 & $\mathrm{~N}_{2}$ & - & $\mathrm{NO}_{3}^{-}$ & + & 0.5 \\
\hline & & 3 & $\mathrm{~N}_{2}$ & + & $\mathrm{NO}_{3}^{-}$ & - & - \\
\hline & & 4 & $\mathrm{~N}_{2}$ & + & $\mathrm{NO}_{3}^{-}$ & + & - \\
\hline \multirow[t]{4}{*}{4} & Soil & 1 & Air & + & - & + & 0.5 \\
\hline & & 2 & Air & + & $\mathrm{NO}_{3}^{-}$ & + & - \\
\hline & & 3 & Air & + & - & + & 4.5 \\
\hline & & 4 & Air & + & $\mathrm{NO}_{3}^{-}$ & + & 4.0 \\
\hline \multirow[t]{4}{*}{5} & Soil & 1 & $\mathrm{~N}_{2}$ & + & $A G$ & + & - \\
\hline & & 2 & $\mathrm{~N}_{2}$ & - & $\mathrm{AG}$ & + & 0.5 \\
\hline & & 3 & $\mathrm{~N}_{2}$ & + & - & + & 0.5 \\
\hline & & 4 & $\mathrm{~N}_{2}$ & - & $\mathrm{AG}+\mathrm{NO}_{3}^{-}$ & + & - \\
\hline \multirow[t]{4}{*}{6} & Sediment & 1 & $\mathrm{~N}_{2}$ & - & - & + & 1.0 \\
\hline & & 2 & $\mathrm{~N}_{2}$ & + & - & + & 0.5 \\
\hline & & 3 & $\mathrm{~N}_{2}$ & + & $\mathrm{NH}_{4}^{+}$ & + & - \\
\hline & & 4 & $\mathrm{~N}_{2}$ & + & $\mathrm{NO}_{3}^{-}$ & + & - \\
\hline \multirow[t]{4}{*}{7} & Sediment & 1 & $\mathrm{~N}_{2}$ & + & - & + & 0.5 \\
\hline & & 2 & $\mathrm{~N}_{2}$ & + & $\mathrm{NO}_{3}^{-}$ & + & - \\
\hline & & 3 & $\mathrm{~N}_{2}$ & + & $\mathrm{AG}$ & + & - \\
\hline & & 4 & $\mathrm{~N}_{2}$ & + & $\mathrm{AG}+\mathrm{NO}_{3}^{-}$ & + & - \\
\hline
\end{tabular}

AG- Acetylglucosamine

Table 4. Plate count medium composition

\begin{tabular}{|c|c|c|c|c|c|}
\hline \multicolumn{2}{|c|}{ Azotobacter Agar } & \multicolumn{2}{|l|}{ Clostridium Agar } & \multicolumn{2}{|c|}{ Fluorescence Denitrification Agar } \\
\hline Ingredient & $\mathrm{g}$ & Ingredient & $\mathrm{g}$ & Ingredient & $\mathrm{g}$ \\
\hline Mannitol & 20.00 & Yeast Extract & 3.00 & Agar & 15.00 \\
\hline Agar & 15.00 & Meat Extract & 10.00 & Proteose peptone No. 3 & 10.00 \\
\hline Soil Extract & 5.00 & Meat Peptone & 5.00 & $\mathrm{KNO}_{3}$ & 2.00 \\
\hline $\mathrm{K}_{2} \mathrm{HPO}_{4}$ & 1.00 & Starch & 1.00 & $\mathrm{~K}_{2} \mathrm{HPO}_{4}$ & 1.50 \\
\hline $\mathrm{MgSO}_{4}$ & 0.20 & $\mathrm{D}(+)$ Glucose & 5.00 & $\mathrm{MgSO}_{2} \cdot 7 \mathrm{H}_{2} \mathrm{O}$ & 1.50 \\
\hline $\mathrm{NaCl}$ & 0.20 & $\mathrm{NaCl}$ & 5.00 & $\mathrm{NaNO}_{2}$ & 0.50 \\
\hline \multirow[t]{3}{*}{$\mathrm{FeSO}_{4}$} & Trace & $\mathrm{CH}_{3} \mathrm{COONa}$ & 3.00 & & \\
\hline & & L-cysteine Hydrochloride & 0.50 & & \\
\hline & & Agar & 12.50 & & \\
\hline
\end{tabular}


Table 5. Gas chromatographic analysis and bacterial count

\begin{tabular}{|c|c|c|c|c|c|c|c|c|c|c|}
\hline \multirow[t]{2}{*}{ Group } & \multirow[t]{2}{*}{ Sample } & \multirow[t]{2}{*}{ Flask } & \multirow{2}{*}{$\begin{array}{l}\text { Gas } \\
\text { Phase }\end{array}$} & \multicolumn{4}{|c|}{ GC Analysis } & \multicolumn{3}{|c|}{ Bacterial Count/g } \\
\hline & & & & $\begin{array}{c}\mathrm{N}_{2} \mathrm{O} \\
(\mu \mathrm{m} / \mathrm{g})\end{array}$ & $\begin{array}{c}\mathrm{CO}_{2} \\
(\mu \mathrm{m} / \mathrm{g})\end{array}$ & $\begin{array}{c}\mathrm{C}_{2} \mathrm{H}_{4} \\
(\mu \mathrm{m} / \mathrm{g})\end{array}$ & $\begin{array}{c}\mathrm{C}_{2} \mathrm{H}_{2} \\
\mu \mathrm{m} / \mathrm{g})\end{array}$ & Az. & $\mathrm{Cl}$. & De. \\
\hline \multirow{4}{*}{1} & \multirow{4}{*}{ Soil } & 1 & $\mathrm{~N}_{2}$ & & & 0.0 & 0 & 0 & 240 & $3.2 \times 10^{5}$ \\
\hline & & 2 & $\mathrm{~N}_{2}$ & & & 1.4 & 0 & & & \\
\hline & & 3 & $\mathrm{~N}_{2}$ & & & 0.0 & 0 & & & \\
\hline & & 4 & $\mathrm{~N}_{2}$ & 0.5 & 20 & 1000.0 & 0 & & & \\
\hline \multirow{4}{*}{2} & \multirow{4}{*}{ Soil } & 1 & $\mathrm{~N}_{2}$ & & & 1400.0 & 11 & & & \\
\hline & & 2 & $\mathrm{~N}_{2}^{2}$ & & & 300.0 & 15 & & & \\
\hline & & 3 & $\mathrm{~N}_{2}$ & 3.0 & 17 & 580.0 & 14 & 0 & 330 & $1.6 \times 10^{6}$ \\
\hline & & 4 & $\mathrm{~N}_{2}$ & 2.0 & 29 & & & & & \\
\hline \multirow{4}{*}{3} & \multirow{4}{*}{ Soil } & 1 & $\mathrm{~N}_{2}$ & 0.3 & 1 & & & & & \\
\hline & & 2 & $\mathrm{~N}_{2}$ & & & 1.0 & 6 & & & \\
\hline & & 3 & $\mathrm{~N}_{2}$ & 0.0 & 23 & & & & & \\
\hline & & 4 & $\mathrm{~N}_{2}$ & 2.0 & 9 & 370.0 & 6 & 260 & 3500 & $2.4 \times 10^{\circ}$ \\
\hline \multirow{3}{*}{4} & \multirow{3}{*}{ Soil } & 1 & Air & & & 167.0 & 14 & 1000 & 0 & 17 \\
\hline & & 2 & Air & 21.0 & 39 & & & & & \\
\hline & & 3 & Air & & 20 & 575.0 & 11 & & & \\
\hline \multirow{4}{*}{5} & \multirow{4}{*}{ Soil } & $\frac{7}{1}$ & $\frac{\mathrm{H}_{11}}{\mathrm{~N}_{2}}$ & 23.0 & & 14000 & $\frac{0}{9}$ & & & \\
\hline & & 2 & $\mathrm{~N}_{2}$ & 10 & 7 & 1400.0 & 8 & 280 & 220 & $21 \times 10^{4}$ \\
\hline & & 3 & $\mathrm{~N}_{2}$ & & & 25000 & 9 & & & \\
\hline & & 4 & $\mathrm{~N}_{2}$ & 4.0 & 7 & & & & & \\
\hline \multirow{4}{*}{6} & \multirow{4}{*}{ Sediment } & 1 & $\mathrm{~N}_{2}$ & & & 2.0 & 14 & & & \\
\hline & & 2 & $\mathrm{~N}_{2}$ & & & 37.0 & 14 & & & \\
\hline & & 3 & $\mathrm{~N}_{2}^{2}$ & 0.2 & 11 & 3.0 & 15 & 0 & 350 & $1.1 \times 10^{5}$ \\
\hline & & 4 & $\mathrm{~N}_{2}^{2}$ & 0.3 & 5 & 1.0 & 14 & & & \\
\hline \multirow{4}{*}{7} & \multirow{4}{*}{ Sediment } & 1 & $\mathrm{~N}_{2}$ & & & 86.0 & 15 & & & \\
\hline & & 2 & $\mathrm{~N}_{2}$ & 2.0 & 5 & & & & & \\
\hline & & 3 & $\mathrm{~N}_{2}$ & 0.1 & 5 & 2.0 & 10 & 0 & 240 & 45 \\
\hline & & 4 & $\mathrm{~N}_{2}$ & 0.6 & 4 & & & & & \\
\hline
\end{tabular}

$\mathrm{Az}=$ Azotobacter Agar; $\mathrm{Cl}=$ Clostridium Agar; $\mathrm{De}=$ Denitrification Agar

In flasks 3 and 4 , which received glucose, there was considerable amount of $\mathrm{C}_{2} \mathrm{H}_{4}$ in flask $4\left(\mathrm{C}_{2} \mathrm{H}_{2}\right.$ added $)$ which suggested that glucose was utilized by nitrogen fixers as a carbon and energy source, while there was no significant $\mathrm{C}_{2} \mathrm{H}_{4}$ production in flask 3 (no $\mathrm{C}_{2} \mathrm{H}_{2}$ added). The total plate count (Azotobacter) and MPN (Clostridium) results in flask 1 showed the absence of nitrogen fixation activity which agreed with the results obtained by gas chromatographic analysis.

\subsection{Group 2 (Soil with $\mathbf{N}_{2} \& \mathbf{N}$-Fertilizers)}

\subsubsection{Denitrification}

The presence of $\mathrm{CO}_{2}$ and accumulation of $\mathrm{N}_{2} \mathrm{O}$ due to the inhibition of the last step (conversion of $\mathrm{N}_{2} \mathrm{O}$ to $\mathrm{N}_{2} \mathrm{O}$ by $\mathrm{C}_{2} \mathrm{H}_{2}$ indicated the proceeding of denitrification process. Since there was no significant differences between flask 3 (no $\mathrm{NH}_{4}{ }^{+}$added) and flask $4\left(\mathrm{NH}_{4}{ }^{+}\right.$ added), this would indicate that, $\mathrm{NH}_{4}{ }^{+}$has no effect on denitrification activity.

\subsubsection{Nitrogen Fixation}

The amounts of $\mathrm{C}_{2} \mathrm{H}_{4}$ produced in flask $2\left(\mathrm{NH}_{4}{ }^{+}\right.$ added) and flask $3\left(\mathrm{NO}_{3}\right.$ added) were 5 and 3 times less than that of flask 1, respectively. The results of flask 2 supported the fact that $\mathrm{NH}_{4}^{+}$assimilated via glucosamine dehydrogenase and the nitrogen fixing organisms use $\mathrm{NH}_{4}{ }^{+}-\mathrm{N}$ for growth as they do not produce the enzymes required for nitrogen fixation. The accumulation of $\mathrm{NH}_{4}^{+}$ switches off nif genes (Leigh and Dodsworth, 2007). In flask 3 the accumulation of $\mathrm{N}_{2} \mathrm{O}$ from denitrification activity (due to the inhibitory effect of $\mathrm{C}_{2} \mathrm{H}_{2}$ on the conversion of $\mathrm{N}_{2} \mathrm{O}$ to $\mathrm{N}_{2} \mathrm{O}$ ) inhibited, to a certain extent, the nitrogenase activity (Newton and Dilworth, 2011). The total plate count and MPN results of flask 3 assured this fact as compared to flask 1 group 1 .

\subsection{Group 3 (Soil with $\mathrm{N}_{2}$ and $\mathrm{NO}_{3}{ }^{-}$)}

\subsubsection{Denitrification}

In flask 1, the denitrification did not take place due to the lack of organic carbon. The traces of $\mathrm{N}_{2} \mathrm{O}$ and $\mathrm{CO}_{2}$ may be from the initial gas phase. The large amount of $\mathrm{CO}_{2}$ and the absence of $\mathrm{N}_{2} \mathrm{O}$ are the result of the denitrification and the complete conversion of $\mathrm{N}_{2} \mathrm{O}$ to $\mathrm{N}_{2}$. The accumulation of $\mathrm{N}_{2} \mathrm{O}$ in flask 4 indicated that, $\mathrm{C}_{2} \mathrm{H}_{2}$ has an inhibitory effect on the conversion of $\mathrm{N}_{2} \mathrm{O}$ to $\mathrm{N}_{2}$ by denitrifiers. This agreed with the results 
obtained from flasks 3 and 4 in group 2. The MPN count assured the activity of denitrification and agreed with the results of the gas chromatograph analysis.

\subsubsection{Nitrogen Fixation}

There was no significant production of $\mathrm{C}_{2} \mathrm{H}_{4}$ in flask 2 , as compared to flask 4 , due to the lack of organic carbon source which agrees with the results of flask 2 group 1. The higher bacterial count in flask 4 showed that the nitrogen fixation process proceeded adequately.

\subsection{Group 4 (Soil with Air \& $\mathrm{NO}_{3}^{-}$)}

\subsubsection{Denitrification}

The only difference between flasks 2 and 4 was the received amount of $\mathrm{H}_{2} \mathrm{O}$. The $4.5 \mathrm{~mL} \mathrm{H}_{2} \mathrm{O}$ in flask 4 encouraged the anaerobic condition in the soil more than that in flask $2\left(0.5 \mathrm{~mL} \mathrm{H}_{2} \mathrm{O}\right)$, since the gas phase was air in both, which gave rise to denitrification earlier in flask 4 and resulted in more $\mathrm{N}_{2} \mathrm{O}$ accumulation. Flask 2 and 4 seem to have much higher $\mathrm{CO}_{2}$ production and $\mathrm{N}_{2} \mathrm{O}$ accumulation than the similar flasks receiving the same treatment (flask 4 group 2, flask 4 group 3, flask 4 group 6, flask 3 group 7). The only difference was the amount of water added. However, flask 2 group 4 has no $\mathrm{H}_{2} \mathrm{O}$ and gained approximately the same amount of $\mathrm{CO}_{2}$ and $\mathrm{N}_{2} \mathrm{O}$. The reason for that is not understood. The MPN showed low numbers of denitrifiers in flask 1 because denitrification did not proceed due to the lack of $\mathrm{NO}_{3}{ }^{-}$or $\mathrm{NO}_{2}{ }^{-}$.

\subsubsection{Nitrogen Fixation}

Comparing flasks 1 and 3 (both contained air as the gas phase), the $4.5 \mathrm{~mL} \mathrm{H}_{2} \mathrm{O}$ in flask 4 encouraged anaerobic conditions in the soil more than that in flask $2\left(0.5 \mathrm{~mL} \mathrm{H}_{2} \mathrm{O}\right)$ which favored the nitrogenase activity. The amount of $\mathrm{C}_{2} \mathrm{H}_{4}$ produced in flask 1 was due to the fact that the soil sample may contain aerobic organisms which consumed the available $\mathrm{O}_{2}$ and brought about an anaerobic condition favoring the activity of nitrogenase. Flasks 3 and 4 received the same amount of $\mathrm{H}_{2} \mathrm{O}$. The lower $\mathrm{C}_{2} \mathrm{H}_{4}$ production in flask 4 was due to the effects of $\mathrm{NO}_{3}^{-}$and $\mathrm{NO}_{2}^{-}$on nitrogenase activity (Newton and Dilworth, 2011) which agreed with the results of flask 3 group $2 . \mathrm{N}_{2} \mathrm{O}$ showed more effect on nitrogenase activity in flask $1\left(0.5 \mathrm{~mL} \mathrm{H}_{2} \mathrm{O}\right)$ than flask $4\left(4.0 \mathrm{~mL} \mathrm{H}_{2} \mathrm{O}\right)$ due to the fact that $\mathrm{N}_{2} \mathrm{O}$ is soluble in water. The amount of $\mathrm{C}_{2} \mathrm{H}_{4}$ produced in flask 1 is much smaller than those of flask 4 group 1 and flask 1 group 2. The reason for that may be due to the effect of oxygen in the gas phase of the first on the nitrogenase activity causing some delay until the aerobes consumed the $\mathrm{O}_{2}$ from the gas phase. Bacterial count of flask 4 showed that the predominant nitrogen fixer was the Azotobacter bacteria which can grow in the presence of $\mathrm{O}_{2}$.

\subsection{Group 5 (Soil with $\mathbf{N}_{2} \&$ Acetylglucosamine)}

\subsubsection{Denitrification}

The results indicated that acetylglucosamine cannot be used as an alternative $\mathrm{N}$ source for denitrification but can be used as organic carbon and energy sources. This finding is reasonable since it has a $\mathrm{C}: \mathrm{N}$ ratio of approximately 5:1. The MPN count indicated the absence of denitrification in flask 3 due to the lack of inorganic nitrogen sources $\left(\mathrm{NO}_{3}^{-}\right.$or $\left.\mathrm{NO}_{2}^{-}\right)$.

\subsubsection{Nitrogen Fixation}

By comparing the results of flask 2 to those of flasks 1 and 3 , it can be concluded that acetylglucosamine was not utilized as a carbon and energy source by nitrogen fixing bacteria. Flask 3 (which has the same treatment as flasks 4 group 1, flask 1 group 2, flask 1 group 4, flack 2 group 6 and flask 1 group 7) seems to have much more production of $\mathrm{C}_{2} \mathrm{H}_{4}$. That could be the result of experimental differences. Bacterial count of flask 2 was consistent with the results of gas chromatography analysis.

\subsection{Group 6 (Sediment with $\mathrm{N}_{2} \&$ N-Fertilizers)}

\subsubsection{Denitrification}

The results indicated that $\mathrm{NH}_{4}^{+}$cannot be used as alternative $\mathrm{N}$ source for denitrification. The MPN indicated that the initial inoculum of denitrifiers in soil samples was higher than that of sediment samples.

\subsubsection{Nitrogen Fixation}

There was no significant $\mathrm{C}_{2} \mathrm{H}_{4}$ produced in flasks 1,2 and 4 . In flask 1 , due to the tack of an organic carbon source which agreed with the results of flask 1 and 2 group 1 and flask 2 group 3. In flask 3, there was an effect of $\mathrm{NH}_{4}{ }^{+}$on nitrogenase which again agrees with the results of flask 2 group 2. In flask 4 , the accumulation of $\mathrm{N}_{2} \mathrm{O}$ affected the nitrogenase activity which is in agreement with the results of flask 3, group 2 and flask 4 group 3. Flask 2, which has the same treatment as flask 4 groups 1 and flask 1 group 2, gained much smaller amount of $\mathrm{C}_{2} \mathrm{H}_{4}$ production. The only difference between the first flask and the others is that the first has sediment sample which suggested that sediment may have less nitrogen fixing organisms than the soil. The data from the bacterial count supports this conclusion.

\subsection{Group 7 (Sediment with $\mathbf{N}_{2}$ and $\mathrm{N}$ - Fertilizers)}

\subsubsection{Denitrification}

The results of flask 2 are in agreement with the results of flask 3 group 2, flask 4, group 3 and flask 4, group 6 which has similar treatments. The results of flask 
3 indicated that aceteleglucosamine cannot be used as alternative $\mathrm{N}$ source for denitrification which is agreement with the results of flask 2, group 5. Flask 4 was expected to yield at least the same amount of $\mathrm{N}_{2} \mathrm{O}$ as flask 4, group 5 which has no glucose (or flasks 1 and 2, group 5 and flask 3, group 7). The reason for the low production of $\mathrm{N}_{2} \mathrm{O}$ is unknown.

\subsubsection{Nitrogen Fixation}

The results indicated that acetylglucosamine is not a recommended substrate for nitrogen fixation. The reasons for that are because either it is not easily utilizable substrate by nitrogen fixers or it may be broken down by some microorganisms to $\mathrm{NH}_{4}^{+}$which inhibits nitrogenase activity. Again the results indicated that the sediment sample had less initial nitrogen fixing organisms that the soil and bacterial count supported this fact too.

\section{DISCUSSION}

\subsection{Denitrification}

Acetylene $(0.1 \mathrm{~atm})$ caused complete inhibition of the reduction of $\mathrm{N}_{2} \mathrm{O}$ to $\mathrm{N}_{2}$ by denitrifiers. During the denitrification, bacteria oxidize organic substances completely to carbon dioxide concomitant with reduction of nitrate or nitrite to nitrous oxide and nitrogen. The ration of carbon dioxide to nitrogen in denitrifying culture corresponded to the theoretical ratio to be expected for complete oxidation of the organic substrate (Koeve and Kahler, 2010). The results of our experiment support this fact. Since $\mathrm{CO}_{2}$ was produced, approximately at the same concentration in the absence and presence of $\mathrm{C}_{2} \mathrm{H}_{2}$ and $\mathrm{N}_{2} \mathrm{O}$ only accumulated in the presence of $\mathrm{C}_{2} \mathrm{H}_{2}$ we can draw the conclusion that acetylene did not inhibit the reduction of $\mathrm{NO}_{3}^{-}$to $\mathrm{NO}_{2}^{-}$and then to $\mathrm{N}_{2} \mathrm{O}$ by the organisms. It is, therefore, interesting that $\mathrm{C}_{2} \mathrm{H}_{2}$ should be an inhibitor of $\mathrm{N}_{2} \mathrm{O}$ reductase. The reported effects of $\mathrm{N}_{3}^{-}$and $\mathrm{CN}^{-}$on denitrification are explained by the effects on specific cytochrome systems (Shoun and Tanimoto, 1991; Yang et al., 2010).

The fact that $\mathrm{C}_{2} \mathrm{H}_{2}$ specifically inhibits $\mathrm{N}_{2} \mathrm{O}$ reduction and causes stoichiometric accumulation of $\mathrm{N}_{2} \mathrm{O}$ during reduction of $\mathrm{NO}_{3}^{-}$and $\mathrm{NO}_{2}^{-}$suggests that $\mathrm{N}_{2} \mathrm{O}$ is an obligatory intermediate in the sequence of steps between $\mathrm{NO}_{3}{ }^{-}$and $\mathrm{N}_{2}$ (Eq. 1). This agrees with the findings of Yoshinari and Knowles (1976) and Cabrera et al. (2011).

Denitrification proceeded most efficiently as indicated by the appearance of $\mathrm{CO}_{2}$ in systems with organic carbon which contained detectable quantities of $\mathrm{N}_{2} \mathrm{O}$ in presence of $\mathrm{C}_{2} \mathrm{H}_{2}$. These observations suggest that the appearance of $\mathrm{CO}_{2}$ and accumulation of $\mathrm{N}_{2} \mathrm{O}$ would be suitable criteria for the presence of denitrifiers in appropriately enriched media. The most probably number (MPN) count supported this suggestion.

Since the results indicated that obligatory requirement for organic carbon for denitrification to take place, they also suggested the possibility of using acetylglucosamine as a carbon and energy source, not as nitrogen source. This is due to the fact that acetylglucosamine has a $\mathrm{C}: \mathrm{N}$ ration of approximately $5: 1$ and some microorganisms may break it down to $\mathrm{NH}_{4}{ }^{+}$ (Scheepers and Raun, 2008) which is not the suitable nitrogen substrate for denitrifiers. It is also noted that $\mathrm{NH}_{4}^{+}$has no effect on denitrification activity. This was similar to the results reported by Park et al. (2010); Veillette et al. (2011) and Qiu et al. (2012).

\subsection{Nitrogen Fixation}

The acetylene reduction test has been used as an assay for nitrogen fixation activity. The results reported here support the validity of the $\mathrm{C}_{2} \mathrm{H}_{2}-\mathrm{C}_{2} \mathrm{H}_{4}$ assay as sensitive analysis for nitrogen - fixing activity. In the assay, acetylene was reduced to ethylene by nitrogenase in which it acts as an alternative substrate to $\mathrm{N}_{2}$ for the enzyme. Reduction of $\mathrm{C}_{2} \mathrm{H}_{2}$ to $\mathrm{C}_{2} \mathrm{H}_{4}$ (Eq. 5), like reduction of $\mathrm{N}_{2}$ to $2 \mathrm{NH}_{3}$ (Eq. 4), requires and enzyme extracts containing nitrogenase and an energy source. The reduction product (ethylene) was easily measured by gas chromatography. $\mathrm{C}_{2} \mathrm{H}_{2}$ is the preferred assay substrate, since more products are formed because of its requirement for 2 electrons versus 6 electrons for $\mathrm{N}_{2}$ (Hardy and Hevelka, 1975; Bertics et al., 2010).

Since the results indicated that obligatory requirement for organic carbon substrate for nitrogen fixation process to proceed, acetylglucosamine was not the suitable substrate for nitrogen fixation process, either because it was not easily utilizable substrate or some microorganisms broke it down to $\mathrm{NH}_{4}{ }^{+}$which inhibits the nitrogenase activity (Park et al., 2010).

The presence of air in the gas phase supresses the nitrogenase activity while addition of $\mathrm{H}_{2} \mathrm{O}$ encourages the anaerobic condition. $\mathrm{NH}_{4}{ }^{+}$inhibited the nitrogenase activity.

\section{CONCLUSION}

The aim of the study was to gain information on the denitrification and nitrogen fixing activities in soil and sediment employing the acetylene technique and assuring the gas chromatography analysis by total plate count and most probably number. The results indicated that acetylene $(0.1$ atm $)$ inhibited $\mathrm{N}_{2} \mathrm{O}$ reduction and caused stoichiometric accumulation of $\mathrm{N}_{2} \mathrm{O}$ during the 
conversion of $\mathrm{NO}_{3}^{-}$to $\mathrm{N}_{2} \cdot \mathrm{N}_{2} \mathrm{O}$ was an obligatory intermediate in the sequence of steps between $\mathrm{N}_{2} \mathrm{O}^{-}$and $\mathrm{N}_{2}$. The appearance of $\mathrm{CO}_{2}$ and accumulation of $\mathrm{N}_{2} \mathrm{O}$ would be suitable criteria for the presence of denitrifiers in appropriately enriched media and the acetylene reduction test is a suitable assay for nitrogen fixing activity. There was an obligatory requirement for organic carbon as a carbon and energy source for denitrification and nitrogen fixation to take place. The results showed that acetylglucosamine can be used as a carbon and energy source for denitrification but not as a nitrogen source (C:N ratio of 5). $\mathrm{NH}_{4}{ }^{+}$has no effect on denitrification activity but it inhibited the nitrogenase activity. The presence of air in the gas phase affects both the denitrification and nitrogen fixing activity while adding $\mathrm{H}_{2} \mathrm{O}$ encouraged anaerobic conditions.

\section{ACKNOWLEGDEMENT}

This research was funded by the Natural Science and Engineering Research Council (NSERC) of Canada.

\section{REFERENCES}

Bertics, V.J., J.A. Sohm, T. Treude, C.E.T. Chow and D.G. Capone et al., 2010. Burrowing deeper into benthic nitrogen cycling: the impact of bioturbation on nitrogen fixation coupled to sulfate reduction. Marine Ecol. Progress Ser., 409: 1-15. DOI: 10.3354/meps08639.

Bothe, H., S.J. Ferguson and W.E. Newton. 2007. Biology of the Nitrogen Cycle. 1st Edn., Elsevier, Amsterdam, ISBN-10: 0444528571, pp: 452.

Burgin, A.J., P.M. Groffman and D.N. Lewis, 2010. Factors regulating denitrification in a riparian wetland. Soil Sci. Soc. Am. J., 74: 1826-1833.

Burns, R.C. and R.F. Hardy, 1975. Nitrogen Fixation in Bacteria and Higher Plants. 1st Edn., Springer, Berlin, ISBN-10: 038707192X, pp: 189.

Cabrera, J.J., C. Sanchez, A.J. Gates, E.J. Bedmar and S. Mesa et al., 2011. The nitric oxide response in plantassociated endosymbiotic bacteria. Biol. Soc. Trans., 39: 1880-1998. DOI: 10.1042/BST20110732.

Calderer, M., O. Gibert, V. Marti, M. Rovira and J.D. Pablo et al., 2010. Denitrification in presence of acetate and glucose for bioremediation of nitrate-contaminated groundwater. Environ. Technol., 31: 799-814. DOI: 10.1080/09593331003667741.
Cranfield, D.E., A.N. Glazer and P.G. Falkowski, 2010. The evolution and future of earth's nitrogen cycle. Science, 330: 192-196. DOI: 10.1126/science. 1186120 .

Dalton, H. and R. Whittenbury, 1976. The acetylene reduction technique as an assay for nitrogenase activity in the methane oxidizing bacterium Methylococcus capsulatus strain bath. Arch. Microbiol., 109: 147-151. DOI: 10.1007/BF00425127.

Dandie, C.E., D.L. Burton, B.J. Zebarth, T.J. Trevors and C. Goyer, 2007. Analysis of denitrification genes and comparison of nosZ, cnorB and 16S rDNA from culturable denitrifying bacteria in potato cropping systems. Syst. Applied Microbiol., 30: 128-138. DOI: 10.1016/j.syapm.2006.05.002.

Gaby, J.C. and D.H. Buckley, 2011. A global census of nitrogenase diversity. Environ. Microbiol., 13: 17901799. PMID: 21559425.

Ghaly, R.A., J.B. Pyke, A.E. Ghaly and V.I. Urgusal, 1999. Physical and thermochemical properties of uncontaminated and diesel-contaminated peat. Energy Sour., 21: 433-451. DOI: 10.1080/00908319950014740.

Hallin, S. and P.E. Lindgren, 1999. PCR detection of genes encoding nitrite reductase in denitrifying bacteria. Applied Environ. Microbiol., 65: 16521658.

Hara, S., Y. Hashidoko, R.V. Desyatkin, R. Hatano and S. Tahara, 2009. High rate of $\mathrm{N}_{2}$ fixation by east siberian cryophilic soil bacteria as determined by measuring acetylene reduction in nitrogen-poor medium solidified with gellan gum. Applied Environ. Microbiol., 75: 2811-2819. DOI: 10.1128/AEM.02660-08.

Hardy, R.W. and U.D. Havelka, 1975. Nitrogen fixation research: A key to world food? Science, 188: 633642. DOI: 10.1126/science.188.4188.633.

Hofstra, N. and A.F. Bouwman, 2005. Denitrification in agricultural soils: Summarizing published data and estimating global annual rates. Nutr. Cycl. Agroecosyst., 72: 267-278. DOI: 10.1007/s10705005-3109-y.

Jetten, M.S., 2008. The microbial nitrogen cycle. Environ. Microbiol., 10: 2903-2909. PMID: 18973618.

Jia, Z. and R. Conrad, 2009. Bacteria rather than Archaea dominate microbial ammonia oxidation in an agricultural soil. Environ. Microbiol., 11: 16581671. PMID: 19236445. 
Keeney, D.R., 1973. The nitrogen cycle in sedimentwater systems. J. Environ. Q., 2: 15-29.

Kim, M., S.Y. Jeong, S.J. Yoon, S.J. Cho and Y.H. Kim et al., 2008. Aerobic denitrification of Pseudomonas putida $\mathrm{AD}-21$ at different $\mathrm{C} / \mathrm{N}$ ratios. J. Biosci. Bioeng., 106: 489-502. DOI: 10.1263/jbb.106.498.

Koeve, W. and P. Kahler, 2010. Heterotrophic denitrification vs. autotrophic anammox-quantifying collateral effects on the oceanic carbon cycle. Biogeosciences, 7: 2327-2337. DOI: 10.5194/bg-72327-2010.

Larrainzar, E., S. Wienkoop, C. Scherling, S. Kempa and R. Ladera et al., 2009. Carbon metabolism and bacteroid functioning are involved in the regulation of nitrogen fixation in Medicago truncatula under drought and recovery. Mol. Plant-Microbe Interact., 22: 1565-1576. DOI: 10.1094/MPMI-22-12-1565.

Leigh, J.A. and J.A. Dodsworth, 2007. Nitrogen regulation in bacteria and archaea. Annual Rev. Microbiol., 61: 349-377. DOI: 10.1146/annurev.micro.61.080706.093409.

Lin, Y.M., J.H. Tay, Y. Liu and Y.T. Hung, 2009. Biological nitrification and denitrification processes. Biolog. Treatment Processes, Handbook Environ. Eng., 8: 539-599. DOI: 10.1007/978-1-60327-156-1 13.

Nakajima, Y., S. Ishizuka, H. Tsuruta, A. Iswandi and D. Murdiyarso. 2005. Microbial processes responsible for nitrous oxide production from acid soils in different land-use patterns in Pasirmayang, central Sumatra, Indonesia. Nutr. Cycl. Agroecosyst., 71: 33-42. DOI: 10.1007/s10705-004-1196-9.

Newton, W.E. and M.J. Dilworth, 2011. Assays of nitrogenase reaction products. Methods Mol. Biol., 766: 105-127. PMID: 21833864.

Ohyama, T., A. Yamazaki, N. Yamashita, T. Kimura and S. Ito et al., 2008. Mechanism of quick and reversible inhibition of soybean nodule growth and nitrogen fixation activity by nitrate and its metabolites. Curr. Plant Sci. Biotechnol. Agric., 42: 89-90. DOI: 10.1007/978-1-4020-8252-8 29.

Park, S., W. Bae and B.E. Rittmann, 2010. Operational boundaries for nitrite accumulation in nitrification based on minimum/maximum substrate concentrations that include effects of oxygen limitation, $\mathrm{pH}$ and free ammonia and free nitrous acid inhibition. Environ. Sci. Technol., 44: 335-342. DOI: $10.1021 / \mathrm{es} 9024244$.

Patriquin, D.G. and R. Knowles, 1974. Denitrifying bacteria in some shallow-water marine sediments: Enumeration and gas production. Can. J. Microbiol., 20: 1037-1041. DOI: 10.1139/m74-160.
Perez, C.A., M.R. Carmona and J.J. Armesto, 2010. Non-symbiotic nitrogen fixation during leaf litter decomposition in an old-growth temperate rain forest of Chiloe Island, southern Chile: Effects of single versus mixed species litter. Austral Ecol., 35: 148-156. DOI: 10.1111/j.1442-9993.2009.02020.x.

Qiu, X., T. Wang, X. Zhong, G. Du and J. Chen, 2012. Screening and characterization of an aerobic nitrifying-denitrifying bacterium from activated sludge. Biotechnol. Bioprocess Eng., 17: 353-360. DOI: 10.1007/s12257-011-0467-y.

Reed, S.C., C.C. Cleveland and A.R. Townsend, 2011. Functional ecology of free-living nitrogen fixation: A contemporary perspective. Annual Rev. Ecol. Evolut. Syst., 42: 489-512. DOI: 10.1146/annurevecolsys-102710-145034.

Robertson, L.A. and J.G. Kuenen, 1990. Combined heterotrophic nitrification and aerobic denitrification in Thiosphaera pantotropha and other bacteria. Antonie Van Leeuwenhoek, 57: 139-152. DOI: 10.1007/BF00403948.

Ross, K.A., J.G. Ehrenfeld and M.V. Patel, 2011. The effects of nitrogen addition on the growth of two exotic and two native forest understory plants. Biol. Ivasions, 13: 2203-2216. DOI: 10.1007/s10530-0110034-7.

Salvagiotti, F., K.G. Cassman, J.E. Specht, D.T. Walters and A. Weiss et al., 2008. Nitrogen uptake, fixation and response to fertilizer $\mathrm{N}$ in Soybeans: A review. Field Crops Res., 108: 1-13. DOI: 10.1016/j.fcr.2008.03.001.

Santos, P.C.D., Z. Fang, S.W. Mason, J.C. Setubal and R. Dixon, 2012. Distribution of nitrogen fixation and nitrogenase-like sequences amongst microbial genomes. BMC Genomics, 13: 162-162. DOI: 10.1186/1471-2164-13-162.

Scheepers, J.S. and W.R. Raun, 2008. Nitrogen in Agricultural Systems. 1st Edn., ASA, Madison, Madison, ISBN-10: 0891181644, pp: 965.

Senbayram, M., R. Chen, A. Budai, L. Bakken and K. Ditter, 2012. N2O emission and the $\mathrm{N}_{2} \mathrm{O} /\left(\mathrm{N}_{2} \mathrm{O}+\mathrm{N}_{2}\right)$ product ratio of denitrification as controlled by available carbon substrates and nitrate concentrations. Agric., Ecosyst. Environ., 147: 4-12. DOI: 10.1016/j.agee.2011.06.022.

Shoun, H. and T. Tanimoto, 1991. Denitrification by the fungus Fusarium oxysporum and involvement of cytochrome $\mathrm{P}-450$ in the respiratory nitrite reduction. J. Biol. Chem., 266: 11078-11082. 
Torrento, C., J. Cama, J. Urmeneta, N. Otero and A. Soler, 2010. Denitrification of groundwater with pyrite and Thiobacillus denitrificans. Chem. Geol., 278: 80-91. DOI: 10.1016/j.chemgeo.2010.09.003

Tremblay, N., Z. Wang and Z.G. Cerovic, 2012. Sensing crop nitrogen status with fluorescence indicators. A review. Agron. Sustain. Dev., 32: 451-464. DOI: 10.1007/s13593-011-0041-1.

Trevors, J.T., 2010. One gram of soil: A microbial biochemical gene library. Antonie Van Leeuwenhoek, 97: 99-106. PMID: 19921459.

Veillette, M., P. Veins, A.A. Ramirez, R. Brzezinski and M. Heitz, 2011. Effect of ammonium concentration on microbial population and performance of a biofilter treating air polluted with methane. Chem. Eng. J., 171: 1114-1123. DOI: 10.1016/j.cej.2011.05.008.

Vitousek, P.M. and S. Hobbie, 2000. Heterotrophic nitrogen fixation in decomposing litter: Patterns and regulation. Ecology, 81: 2366-2376. DOI: $10.1890 / 0012-$ 9658(2000)081[2366:HNFIDL]2.0.CO;2.
Ward, B.B., 1995. Diversity of culturable denitrifying bacteria: Limits of rDNA RFLP analysis and probes for the functional gene, nitrite reductase. Arch. Microbiol., 163: 167-175.

Warneke, S., L.A. Schipper, M.G. Matiasek, K.M. Scow and S. Cameron et al., 2011. Nitrate removal, communities of denitrifiers and adverse effects in different carbon substrates for use in denitrification beds. Water Res., 45: 5463-5475. DOI: 10.1016/j.watres.2011.08.007.

Yang, Y., A. Dey and R.A. Decreau, 2010. Spectroscopic characterization and competitive inhibition studies of azide binding to a functional NOR model. Eur. J. Inorganic Chem., 2010: 48704874. DOI: 10.1002/ejic.201000566.

Yoshinari, T. and R. Knowles, 1976. Acetylene inhibition of nitrous oxide reduction by denitrifying bacteria. Biochem. Biophys. Res. Commun. 69: 705710. DOI: 10.1016/0006-291X(76)90932-3.

Zhao, Y., M. Xu and J. Belnap, 2010. Potential nitrogen fixation activity of different aged biological soil crusts from rehabilitated grasslands of the hilly Loess Plateau, China. J. Arid Environ., 74: 11861191. DOI: 10.1016/j.jaridenv.2010.04.006. 